\title{
The effects for growth of perioperative enteral feeding in neonates with TGA
}

\author{
H Ebishima*, K Kurosaki, I Shiraishi \\ From ESICM LIVES 2015 \\ Berlin, Germany. 3-7 October 2015
}

\section{Introduction}

Although the physical and nutritional benefits of early enteral feeding in neonates are well-known, it has not yet to be controversial that early enteral feeding in preoperative term neonates with unstable hemodynamics due to congenital heart diseases is safe or risky.

\section{Objectives}

This retrospective study was designed to assess the effects for growth of enteral feeding in neonates with transposition of the great arteries (TGA) awaiting surgical repair.

\section{Methods}

We reviewed records of 25 neonates, less than 28 days of age, with TGA undergoing surgical repair between January 2011 and December 2014.

\section{Results}

They were 18 enteral feeding recipients and 7 nonrecipients in preoperative term. Among 2 groups, there were no differences in sex, gestational age, body weight at birth, or day of age at the operation. Multivariable analysis was performed to evaluate preoperative calorie intake, postoperative length of stay, durations of ventilation and vasopressor use and body weight gain. There were no differences in postoperative length of stay or durations of ventilation and vasopressor use. Enteral feeding recipients were associated with high calorie intake in preoperative term and large body weight gain after operation, especially during 6 months after operation, large weight increase per day (least square mean difference, 6 gram per day, $\mathrm{p}=0.04)$. No patients had necrotizing enterocolitis.

National Cerebral and Cardiovascular Center, Pediatric Cardiology, Suita, Japan

\section{SpringerOpen ${ }^{\circ}$}

\section{Conclusions}

Because this is a small retrospective review, conclusions regarding the safety of enteral feeding in TGA neonates are speculative. However, in this analysis of infants with TGA undergoing surgery, preoperative enteral feedings was well tolerated and beneficial to the growth.

Published: 1 October 2015

doi:10.1186/2197-425X-3-S1-A495

Cite this article as: Ebishima et al:: The effects for growth of

perioperative enteral feeding in neonates with TGA. Intensive Care Medicine Experimental 2015 3(Suppl 1):A495.
Submit your manuscript to a SpringerOpen ${ }^{\circ}$ journal and benefit from:

- Convenient online submission

- Rigorous peer review

- Immediate publication on acceptance

- Open access: articles freely available online

- High visibility within the field

- Retaining the copyright to your article 